\title{
IVIIIf Pendugaan potensi air tanah dan hubungannya dengan kualitas air tanah serta implementasi pada pembelajaran fisika
}

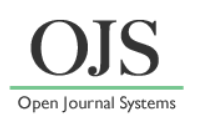

\author{
Roni Putra $^{1 *}$, Eko Swistoro ${ }^{2}$, M. Farid ${ }^{3}$ \\ ${ }^{1}$ Pascasarjana Pendidikan IPA FKIP Universitas Bengkulu, Bengkulu \\ ${ }^{2}$ Pendidikan Fisika FKIP Universitas Bengkulu, Bengkulu \\ ${ }^{3}$ Jurusan Fisika FMIPA Universitas Bengkulu, Bengkulu \\ *Email: roniputra31@gmail.com
}

\begin{abstract}
ABSTRAK
Penelitian ini bertujuan untuk: mendeskripsikan potensi air tanah pada daerah penelitian dengan menggunakan metode geolistrik; menentukan besar resistivitas listrik yang terkandung pada lapisan air tanah dengan menggunakan metode geolistrik; mengetahui hubungan antara besar resistivitas listrik yang terkandung pada lapisan air tanah dengan parameter kualitas air sumur melalui uji laboratorium; mengetahui peningkatan hasil belajar siswa pada kelompok tinggi, sedang, dan rendah setelah menggunakan model pembelajaran langsung (direct instruction); mengetahui perbedaan hasil belajar siswa pada kelompok tinggi, sedang, dan rendah dengan menggunakan model pembelajaran langsung (direct instruction) pada konsep hukum ohm pelajaran fisika kelas XII Matematika dan Ilmu Alam 2 Madrasah Aliyah Negeri Seluma. Penelitian pendidikan yang dilakukan kuasi eksperimen One Group Pretest-Posttest Design untuk mengetahui efektivitas penggunaan model pembelajaran langsung (direct instruction) dalam proses pembelajaran fisika dengan mengetahui peningkatan nilai pretest dan posttest media LKS. Pada penelitian sains untuk mengetahui potensi air tanah menggunakan metode geolistrik konfigurasi wenner dan didapatkan nilai resistivitas dari inversi 2D software RES2DINV 31,8 $\Omega \mathrm{m}-147$ $\Omega \mathrm{m}$ yang berpotensi air tanah. Hubungan antara parameter uji kualitas air dengan nilai resistivitas didapatkan nilai korelasi $\mathrm{R}^{2}=0,5818$ dikriterikan mempunyai korelasi kuat. Hasil analisis penelitian pendidikan dengan model pembelajaran langsung (direct instruction) setelah diuji Anova Satu Jalur (One Way Anova) diperoleh $\mathrm{F}_{\text {hitung }}$ lebih besar dari $\mathrm{F}_{\text {tabel }}(15,42>3,59)$, maka hipotesis alternatif $\left(\mathrm{H}_{\mathrm{a}}\right)$ diterima, sehingga penggunaan model pembelajaran langsung (direct instruction) efektif.
\end{abstract}

Kata kunci: Potensi air tanah; metode geolistrik; kualitas air tanah; pembelajaran fisika.

\section{PENDAHULUAN}

Air tanah merupakan salah satu sumber daya penting bagi kehidupan dan mempunyai nilai strategis. Air tanah terbentuk dari air hujan yang menyerap ke dalam tanah dan bergerak sepanjang zona aerasi dan jalur-jalur kapiler yang akhirnya mencapai muka air tanah dan menjadi bagian dari sistem air tanah (Sangkoro, 1979).

Secara geografis wilayah Kabupaten Seluma beradadi Pantai Barat Pulau Sumatera bagian Selatan yang berada pada koordinat garis lintang dan bujur yaitu $03^{\circ} 49^{\prime} 55,66^{\prime \prime}$ LS $04^{\circ} 21^{\prime} 40,22^{\prime \prime}$ LS dan 101 17'27,57" BT $102^{\circ} 59^{\prime} 40,54^{\prime \prime}$ BT. Luas wilayah darat Kabupaten Seluma adalah seluas $\pm 2.400,44 \mathrm{~km}^{2}$ atau $12,13 \%$ dari luas Provinsi Bengkulu dan Wilayah Laut seluas $\pm 1.728,02 \mathrm{~km}^{2}$ sehingga total keseluruhan luas Kabupaten Seluma adalah 4.128,46 km² (Lestari, 2014). Daerah pesisir pantai Desa Kungkai Baru terletak di Kecamatan Air Periukan Kabupaten Seluma Provinsi Bengkulu. Masyarakat di pesisir pantai Desa Kungkai Baru pada umumnya masih menggunakan air sumur dangkal sebagai sumber air bersih dan air minum. Air sumur dangkal persediaannya sangat terbatas pada musim kemarau dan di beberapa tempat terkena intrusi air laut. Hingga saat ini, layanan air PDAM belum menjangkau daerah pesisir. Penggunaan air bersih semakin bertambah seiring dengan pertambahan jumlah penduduk dan pertumbuhan ekonomi. Kegiatan masyarakat Desa Kungkai 
Baru yang mayoritas bergerak dibidang pertanian, perkebunan dan pengembangan di berbagai sektor sangat bergantung pada ketersediaan sumber air bersih. Guna mencukupi kebutuhan air bersih, maka perlu mengoptimalkan sumber air bersih yang ada di daerah tersebut dan melakukan uji laboratorium dengan mengambil sampel air sumur untuk mengetahui kualitas air yang bersih dan layak dikonsumsi.

Metode geolistrik merupakan metode yang banyak sekali digunakan dan hasilnya cukup baik yaitu untuk memperoleh gambaran mengenai lapisan tanah dibawah permukaan dan kemungkinan terdapatnya air tanah (Suhendra, 2005). Pendugaan geolistrik ini didasarkan pada kenyataan bahwa material yang berbeda akan mempunyai tahanan jenis yang berbeda apabila dialiri arus listrik (Telford, dkk. 1976). Pengukuran resistivitas dilakukan dengan instrumen berupa resistivity meter sebagai unit utamanya, dilengkapi oleh beberapa perangkat penunjang seperti batang-batang elektroda, kabel-kabel penghubung dan sumber daya listrik. Prinsip pengukuran geolistrik resistivitas pada dasarnya cukup sederhana. Mengacu pada Hukum Ohm, V=I.R, yaitu dengan menginjeksikan/ menghantarkan arus listrik I ke dalam tanah (tanah/bumi sebagai medium hantar berhambatan R) melalui sepasang elektroda arus, dan mengukur beda potensial $\mathrm{V}$ yang timbul melalui sepasang elektroda potensial pada jarak tertentu dari elektroda arus. Resistivitas terukur umumnya dinyatakan dalam satuan Ohm-meter $(\Omega \mathrm{m})$.

Setiap guru harus memiliki keahlian di dalam memilih model pengajaran yang dipakai sehari-hari dikelas. Dari beberapa model pengajaran yang baru, salah satu bentuk model penyajian materi yang penting untuk diketahui adalah model pengajaran langsung (direct instruction). Model pengajaran langsung dirancang secara khusus untuk mengembangkan pengetahuan prosedural dan pengetahuan deklaratif (Nur, 2000:4-5).

Dalam proses pembelajaran fisika, Lembar kerja siswa (LKS) dapat digunakan sebagai alat bantu. Dalam pembelajaran fisika khususnya dengan pokok bahasan sifat resistivitas atau hambatan jenis, hal yang perlu diperhatikan adalah bahwa materi pelajaran tersebut seharusnya dilakukan secara praktik di Laboratorium. Guru dituntut juga untuk menyiapkan suatu perencanaan proses pembelajaran. Setiap guru pada satuan pendidikan berkewajiban menyusun perangkat pembelajaran seperti LKS secara lengkap dan sistematis (Ratnasari, 2013). Dari uraian permasalahan yang diungkapkan diatas yaitu permasalahan mengenai potensi air tanah terhadap kualitas air tanah dan implementasinya pada pembelajaran siswa dengan menggunakan LKS. Oleh karena itu, peneliti tertarik untuk melakukan penelitian mengenai pendugaan potensi air tanah menggunakan metode geolistrik dan hubungannya dengan kualitas air tanah serta implementasinya pada pembelajaran fisika.

\section{METODE PENELITIAN}

Ada dua jenis penelitian yang penulis lakukan. Jenis penelitian yang pertama adalah penelitian sains yang bertujuan mengetahui potensi air tanah dengan menggunakan metode geolistrik konfigurasi wenner dan hubungannya dengan kualitas air tanah. Penelitian yang kedua adalah penelitian pendidikan. Penelitian pendidikan ini merupakan jenis penelitian quasi eksperimen dengan desain One Groups PretestPosttest terhadap pelaksanaan pembelajaran menggunakan Model pembelajaran langsung (direct instruction) untuk mengetahui efektivitas belajar siswa dan mengetahui peningkatan nilai pretest dan posttest siswa. Penelitian sains dilaksanakan pada bulan Nopember 2016 s.d Maret 2017 di Pesisir Pantai Kungkai Baru Kecamatan Air Periukan Kabupaten Seluma Provinsi Bengkulu dengan sample penelitian titik lintasan pengukuran dengan metode geolistrik untuk menentukan potensi air tanah di daerah pesisir pantai Desa Kungkai Baru dan populasi penelitian daerah pesisir Desa Kungkai Baru yang berpotensi mengandung air tanah.

Dalam Penelitian Pendidikan yang menjadi subjek penelitian yang diteliti adalah seluruh siswa kelas XII Matematika dan Ilmu Alam (MIA) Madrasah Aliyah Negeri Seluma tahun ajaran 2016/2017. Banyaknya subjek yang akan diteliti adalah 40 Siswa yang terdiri dari 2 kelas dan yang menjadi Sampel adalah kelas XII MIA 2 sebanyak 20 Siswa. 
Desain yang digunakan dalam penelitian ini adalah desain pretest-posttest kelompok tunggal (One Group Pretest-Posttest Design) menurut Arikunto (2006). Pretest dan Posttest dilaksanakan dengan menggunakan tes yang sama. Desainnya dapat dilihat seperti Tabel 1 .

Tabel 1. Desain penelitian

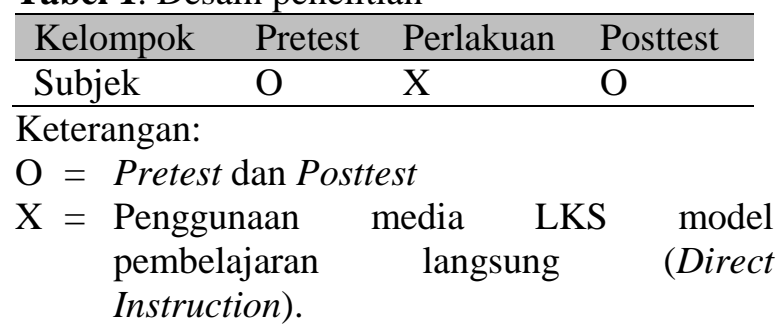

Instrumen penelitian terdiri atas perangkat pembelajaran (RPP dan LKS) dan instrumen pengumpulan data (soal pretest dan posttest sebanyak 15 soal). Sebelum digunakan, semua instrumen tersebut dilakukan uji validitas. Untuk RPP dan LKS hanya dilakukan uji validitas isi oleh tiga orang guru fisika. Sedangkan tes kognitif dilakukan uji validitas isi dan reliabilitas (ICC) oleh tiga orang guru fisika (sebagai judgment experts). Setelah itu, soal diujikan di lapangan. Hasil yang diperoleh digunakan untuk menguji validitas, reliabilitas, tingkat kesukaran dan daya beda soal. Berdasarkan hasil uji tersebut diperoleh: 1) tes kognitif yang diterima 15 butir dengan realibilitas tinggi $\left(r_{11}=0,8854\right)$; 2) sebanyak 5 butir soal tidak valid dan dibuang. Data penelitian ini berupa hasil belajar kognitif. Data tersebut dianalisis dengan statistik deskriptif dan Uji Anova Satu Jalur (One Way Anova).

\section{HASIL DAN PEMBAHASAN}

Penelitian yang dilakukan mengenai pendugaan potensi air tanah menggunakan metode geolistrik dan hubungannya dengan kualitas air tanah serta implementasinya pada pembelajaran fisika. Penelitian Sains dilaksanakan pada bulan Maret 2017 di Pesisir Pantai Kungkai Baru Kecamatan Air Periukan Kabupaten Seluma Propinsi Bengkulu. Penelitian ini menggunakan metode geolistrik untuk mengetahui potensi air tanah menggunakan konfigurasi Wenner dan uji laboratorium sampel air sumur yang diambil untuk mengetahui kualitas airnya. Setelah dilakukan pengukuran dan pengambilan data selanjutnya data diolah dengan menggunakan software RES2DINV yang bertujuan untuk menentukan lapisan-lapisan air tanah/batuan. Hasil dari pengolahan data dengan software RES2DINV seperti terlihat pada beberapa gambar berikut:

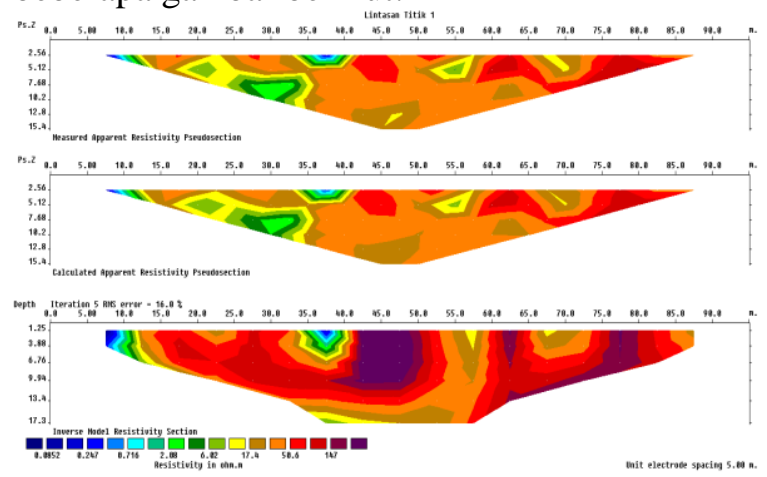

Gambar 1. Penampang hasil inversi 2-D pada Lintasan Titik 1

Tabel 2. Konfigurasi citra warna untuk resistivitas dan jenis tanah/batuan Lintasan titik 1
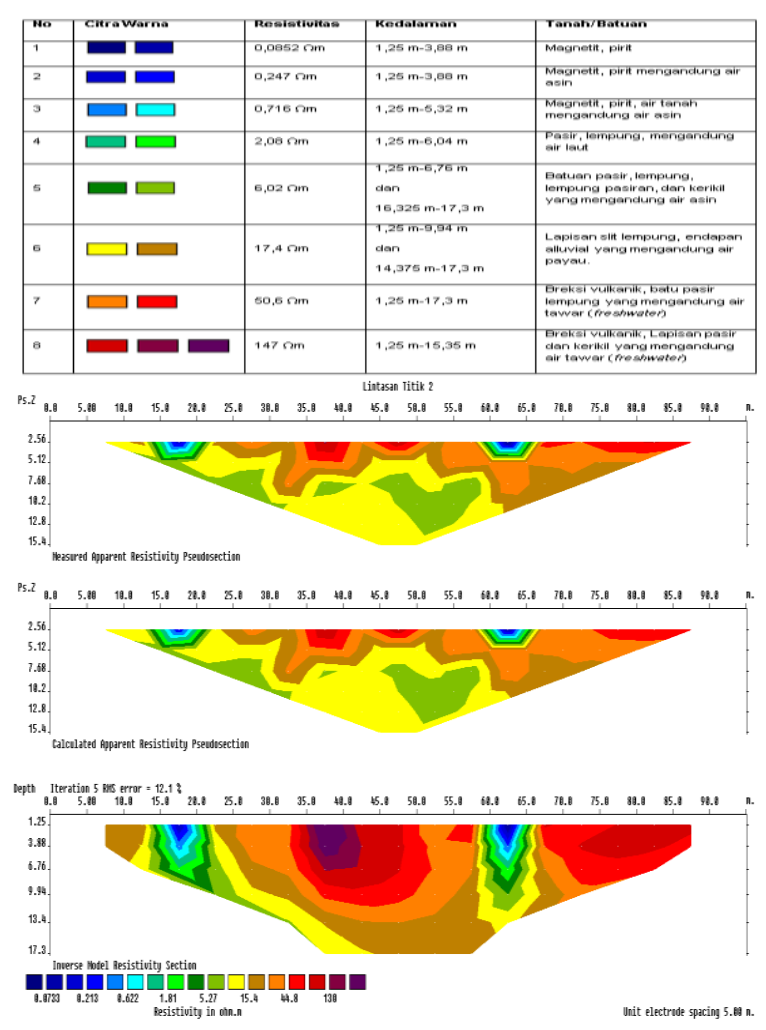

Gambar 2. Penampang hasil inversi 2-D pada Lintasan Titik 2 
Tabel 3. Konfigurasi citra warna untuk resistivitas dan jenis tanah/batuan Lintasan titik 2

\begin{tabular}{|c|c|c|c|c|}
\hline No & Citra Warna & Resistivitas & Kedalaman & Tamah/Batuan \\
\hline 1 & & $0.0733 \mathrm{~nm}$ & $1.25 \mathrm{~m}-3.22 \mathrm{~m}$ & Magnetit, pirit \\
\hline 2 & $\square$ & $0.213 \mathrm{~nm}$ & $1,25 \mathrm{~m}-3.88 \mathrm{~m}$ & $\begin{array}{l}\text { Magnetit, pirit } \\
\text { mengandung air asin }\end{array}$ \\
\hline 3 & $\square \square$ & $0.622 \mathrm{~nm}$ & $1,25 \mathrm{~m}-5,32 \mathrm{~m}$ & $\begin{array}{l}\text { Magnetit, pirit, air tanah } \\
\text { mengandung air asin }\end{array}$ \\
\hline 4 & $\square \square$ & $1.81 \mathrm{~nm}$ & $1,25 \mathrm{~m}-7.82 \mathrm{~m}$ & $\begin{array}{l}\text { Magnetit, pirit, air tanah } \\
\text { mengandung air asin }\end{array}$ \\
\hline 5 & $\square \square$ & $5.27 \mathrm{\Omega m}$ & $1,25 \mathrm{~m}-11,67$ & $\begin{array}{l}\text { Batuan pasir, lempung, } \\
\text { lempung pasiran, dan } \\
\text { kerikil yang mengandung } \\
\text { air asin }\end{array}$ \\
\hline 5 & $\square \square$ & $15.4 \mathrm{~nm}$ & $1,25 \mathrm{~m}-17.3 \mathrm{~m}$ & $\begin{array}{l}\text { Lapisan slit lempung. } \\
\text { endapan alluvial yang } \\
\text { mengandung air payau. }\end{array}$ \\
\hline 7 & $\square$ & $44,8 \mathrm{~nm}$ & $1,23 \mathrm{~m}-13.4 \mathrm{~m}$ & $\begin{array}{l}\text { Breksi wulkanik, batu } \\
\text { pasir lempung yang } \\
\text { mengandung air tawrar } \\
\text { (frestwwater) }\end{array}$ \\
\hline $\mathrm{a}$ & & $130 \mathrm{om}$ & $1.25 \mathrm{~m}-8.88 \mathrm{~m}$ & $\begin{array}{l}\text { Breksi wulkanik, Lapisan } \\
\text { pasir dan kerikil yang } \\
\text { mengandung air tawar } \\
\text { (fresinwater) }\end{array}$ \\
\hline
\end{tabular}

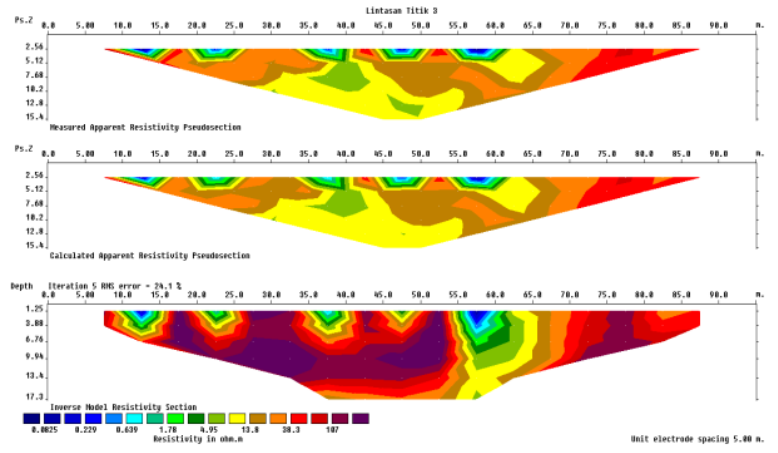

Gambar 3. Penampang hasil inversi 2-D pada Lintasan Titik 3

Tabel 4. Konfigurasi citra warna untukresistivitas dan jenis tanah/batuan Lintasan Titik 3

\begin{tabular}{|c|c|c|c|c|}
\hline No & Citra Warna & Resistivitas & Kedalaman & Tanah/Batuan \\
\hline 1 & 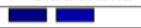 & $0,0825 \mathrm{sm}$ & $1,25 \mathrm{~m}-1,91 \mathrm{~m}$ & Magnetit, pirit \\
\hline 2 & 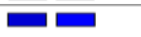 & $0.229 \mathrm{sm}$ & $1,25 \mathrm{~m}-3,22 \mathrm{~m}$ & $\begin{array}{l}\text { Magnetit, pirit } \\
\text { mengandung air asin }\end{array}$ \\
\hline 3 & $\square \square$ & $0,639 \Omega \mathrm{m}$ & $1,25 \mathrm{~m}-5,32 \mathrm{~m}$ & $\begin{array}{l}\text { Magnetit, pirit, air tanah } \\
\text { mengandung air asin }\end{array}$ \\
\hline 4 & $\square \square$ & $1,78 \mathrm{sm}$ & $1,25 \mathrm{~m}-7,82 \mathrm{~m}$ & $\begin{array}{l}\text { Magnetit, pirit, air tanah } \\
\text { mengandung air asin }\end{array}$ \\
\hline 5 & $\square \square$ & $4.95 \mathrm{sm}$ & $1,25 \mathrm{~m}-11,67 \mathrm{~m}$ & $\begin{array}{l}\text { Batuan pasir, lempung, } \\
\text { lempung pasiran, dan } \\
\text { kerikit yang mengandung } \\
\text { air asin }\end{array}$ \\
\hline 6 & $\square \square$ & $13,8 \mathrm{sm}$ & $1,25 \mathrm{~m}-17,3 \mathrm{~m}$ & $\begin{array}{l}\text { Lapisan slit lempung. } \\
\text { endapan alluvial yang } \\
\text { mengandung air payau. }\end{array}$ \\
\hline 7 & $\square \square$ & $38,3 \mathrm{sm}$ & $1,25 \mathrm{~m}-16,33 \mathrm{~m}$ & $\begin{array}{l}\text { Breksi vulkanik, batu pasir } \\
\text { lempung yang } \\
\text { mengandung air tawar } \\
\text { (frestrwater) }\end{array}$ \\
\hline 8 & & $107 \mathrm{sm}$ & $\begin{array}{l}1,25 \mathrm{~m}-14,38 \mathrm{~m} \\
\text { dan } \\
6,04 \mathrm{~m}-13,4 \mathrm{~m}\end{array}$ & $\begin{array}{l}\text { Breksi vulkanik, Lapisan } \\
\text { pasir dan kerikil yang } \\
\text { mengandung air tawar } \\
\text { (frestwwater) }\end{array}$ \\
\hline
\end{tabular}

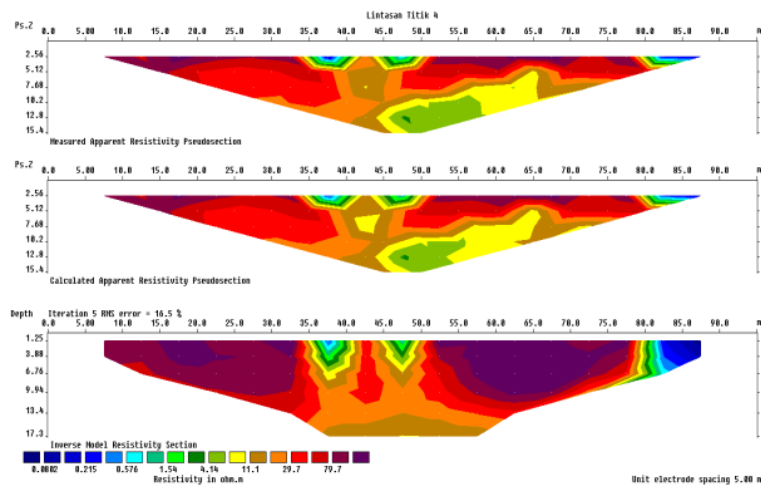

Gambar 4. Penampang hasil inversi 2-D pada Lintasan Titik 4

Tabel 5. Konfigurasi citra warna untukresistivitas dan jenis tanah/batuan Lintasan Titik 4

\begin{tabular}{|c|c|c|c|c|}
\hline No & Citra Warna & Resistivitas & Kedalaman & Tanah/Batuan \\
\hline 1 & 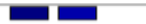 & $0,0802 \mathrm{sm}$ & $1,25 \mathrm{~m}-3,88 \mathrm{~m}$ & Magnetit, pirit \\
\hline 2 & 0 & $0.215 \Omega \mathrm{m}$ & $1,25 \mathrm{~m}-5,32 \mathrm{~m}$ & $\begin{array}{l}\text { Magnetit, pirit } \\
\text { mengandung air asin }\end{array}$ \\
\hline 3 & $\square \square$ & $0,576 \mathrm{sm}$ & $1,25 \mathrm{~m}-6,76 \mathrm{~m}$ & $\begin{array}{l}\text { Magnetit, pirit, air tanah } \\
\text { mengandung air asin }\end{array}$ \\
\hline 4 & $\square \square$ & $1,54 \mathrm{sm}$ & $1,25 \mathrm{~m}-7,82 \mathrm{~m}$ & $\begin{array}{l}\text { Magnetit, pirit, air tanah } \\
\text { mengandung air asin }\end{array}$ \\
\hline 5 & $\square \square$ & $4,14 \mathrm{gm}$ & $1,25 \mathrm{~m}-7,82 \mathrm{~m}$ & $\begin{array}{l}\text { Batuan pasir, lempung, } \\
\text { lempung pasiran, dan } \\
\text { kerikil yang mengandung } \\
\text { air asin }\end{array}$ \\
\hline 6 & $\square \square$ & $11,1 \mathrm{gm}$ & $\begin{array}{l}1,25 \mathrm{~m}-8,88 \mathrm{~m} \\
\mathrm{dan} \\
13,4 \mathrm{~m}-17,3 \mathrm{~m}\end{array}$ & $\begin{array}{l}\text { Lapisan slit lempung. } \\
\text { endapan alluvial yang } \\
\text { mengandung air payau. }\end{array}$ \\
\hline 7 & $\square \square$ & $29,7 \mathrm{~cm}$ & $1,25 \mathrm{~m}-16,33 \mathrm{~m}$ & $\begin{array}{l}\text { Lapisan slit lempung. } \\
\text { endapan alluvial yang } \\
\text { mengandung air payau }\end{array}$ \\
\hline 8 & & $79.7 \mathrm{sm}$ & $\begin{array}{l}1,25 \mathrm{~m}-13,4 \mathrm{~m} \\
\text { dan } \\
4,6 \mathrm{~m}-13,4 \mathrm{~m}\end{array}$ & $\begin{array}{l}\text { Breksi vulkanik, batu } \\
\text { pasir, pasir dan kerikal } \\
\text { yang mengandung air } \\
\text { tawar (frestrwater) }\end{array}$ \\
\hline
\end{tabular}
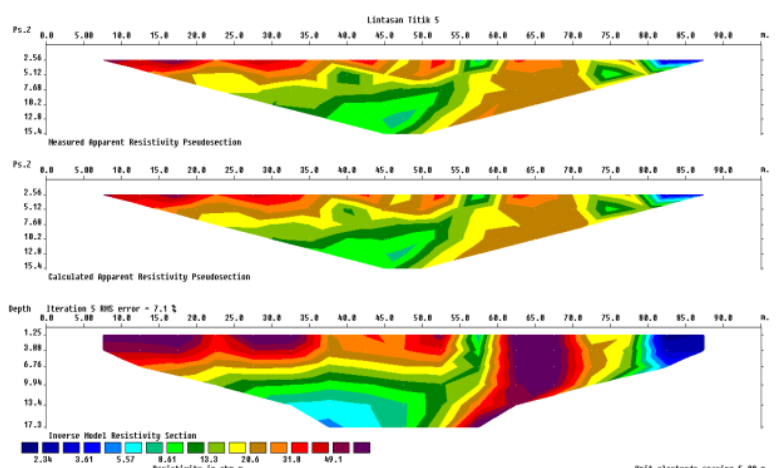

Gambar 5. Penampang hasil inversi 2-D pada Lintasan Titik 5 
Tabel 6. Konfigurasi citra warna untuk resistivitas dan jenis tanah/batuan Lintasan Titik 5
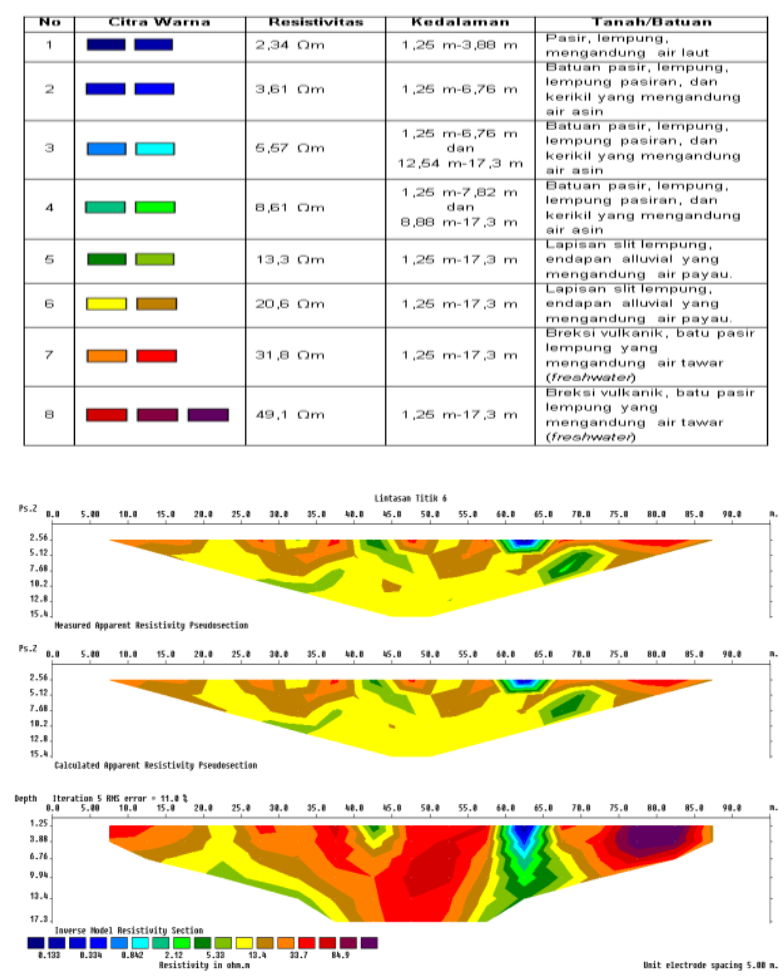

Gambar 6. Penampang hasil inversi 2-D pada Lintasan Titik 6

Tabel 7. Konfigurasi citra warna untukresistivitas dan jenis tanah/batuan Lintasan Titik 6

\begin{tabular}{|c|c|c|c|c|}
\hline No & Citra Warna & Resistivitas & Kodalaman & Tanah/Batuan \\
\hline 1 & $-\pi$ & $0.133 \mathrm{~cm}$ & $1.25 \mathrm{~m}-2.57 \mathrm{~m}$ & $\begin{array}{l}\text { Magnetit, pirit } \\
\text { mengandung air asin }\end{array}$ \\
\hline 2 & ש & $0,334 \mathrm{~cm}$ & $1.25 \mathrm{~m}-4.8 \mathrm{~m}$ & $\begin{array}{l}\text { Magnetit, pirt } \\
\text { mengandung air asin }\end{array}$ \\
\hline 3 & $\square \square$ & $0,842 \mathrm{sm}$ & $1,25 \mathrm{~m}-8,78 \mathrm{~m}$ & $\begin{array}{l}\text { Magnetit, pirit, air tanah } \\
\text { mengandung air asin }\end{array}$ \\
\hline 4 & $\square \square$ & $2,12 \mathrm{sm}$ & $1,25 \mathrm{~m}-11,67 \mathrm{~m}$ & $\begin{array}{l}\text { Pasir, lempung, } \\
\text { mengandung air laut }\end{array}$ \\
\hline 5 & $\square \square$ & $5.33 \mathrm{dm}$ & $\begin{array}{c}1,25 \mathrm{~m}-17,3 \mathrm{~m} \\
\text { dan } \\
8,78 \mathrm{~m}-18,33 \mathrm{~m}\end{array}$ & $\begin{array}{l}\text { Batuan pasiri lempung. } \\
\text { lempung pasiran, dan } \\
\text { kerikit yang } \\
\text { mengandung air asin }\end{array}$ \\
\hline B & $\square \square$ & $13,4 \mathrm{sm}$ & $1,25 \mathrm{~m}-17,3 \mathrm{~m}$ & $\begin{array}{l}\text { Lapisan slit lempung. } \\
\text { endapan alluvial yang } \\
\text { mengandung air payau. }\end{array}$ \\
\hline 7 & $\square \square$ & $33.7 \mathrm{sm}$ & $1,25 \mathrm{~m}-17.3 \mathrm{~m}$ & $\begin{array}{l}\text { Breksi vulkanik, batu } \\
\text { pasir lempung yang } \\
\text { mengandung air tawar } \\
\text { (frestwater) }\end{array}$ \\
\hline 日 & $\square=$ & $84,9 \mathrm{~cm}$ & $1.25 \mathrm{~m}-13,4 \mathrm{~m}$ & $\begin{array}{l}\text { Breksi vulkanik, batu } \\
\text { pasir pasir dan kerikit } \\
\text { yang mengandung air } \\
\text { tawar (fresthwater) }\end{array}$ \\
\hline
\end{tabular}

Berdasarkan kontur penampang hasil inversi 2-D, maka pola sebaran resistivitas tiap lintasan adalah sebagai berikut:

- Berdasarkan Gambar 1 penampang lintasan titik 1. Menurut Loke (1999), nilai resistivitas untuk batuan atau lapisan tanah yang mengandung air tanah tawar (freshwater) adalah sebesar $30-100 \Omega \mathrm{m}$. Berdasarkan Gambar 1 penampang bawah permukaan, pada air tanah lintasan titik 1, freshwater diperkirakan bagian yang berwarna orange hingga kemerahan dengan nilai range resistivitas $\geq 50,6 \Omega \mathrm{m}$.

- Berdasarkan Gambar 2 penampang lintasan titik 2 freshwater diperkirakan bagian yang berwarna orange - merah dengan nilai resistivitas, yaitu $44,8 \Omega \mathrm{m}$.

- Berdasarkan Gambar 3 penampang lintasan titik 3 freshwater diperkirakan bagian yang berwarna orange-merah nilai resistivitas yaitu $38,3 \Omega \mathrm{m}$.

- Berdasarkan Gambar 4 penampang lintasan titik 4 freshwater diperkirakan bagian yang berwarna kemerahan nilairesistivitas, yaitu $79,7 \Omega \mathrm{m}$.

- Berdasarkan Gambar 5 penampang lintasan titik 5 freshwater diperkirakan bagian yang berwarna orange-merah nilai resistivitas yaitu $31,8 \Omega \mathrm{m}-49,1 \Omega \mathrm{m}$.

- Berdasarkan Gambar 6 penampang lintasan titik 6 freshwater diperkirakan bagian yang berwarna orange - merah nilai resistivitas $33,7 \Omega \mathrm{m}-84,9 \Omega \mathrm{m}$.

Dari hasil analisis data uji korelasi menggunakan microsoft excel 2010 diperoleh grafik hubungan antara parameter air berupa TDS, pH, dan Kekeruhan dengan nilai resistivitas hasil inversi 2D software RES2DINV. Adapun nilai korelasi 0,6293 dikriteriakan mempunyai korelasi yang kuat yaitu antara parameter TDS dan nilai resistivitas. Hubungan dari $\mathrm{pH}$ terhadap nilai resistivitas mempunyai korelasi sebesar 0,8389 dikriteriakan korelai sangat kuat. Begitupun dengan parameter kekeruhan yang mempunyai korelasi sebesar 0,9301 dikriteriakan korelai sangat kuat. Pada grafik hubungan antara skor nilai parameter uji kualitas air dengan nilai resistivitas didapatkan nilai korelasi $\mathrm{R}^{2}=0,5818$ dikriterikan mempunyai korelasi kuat. 


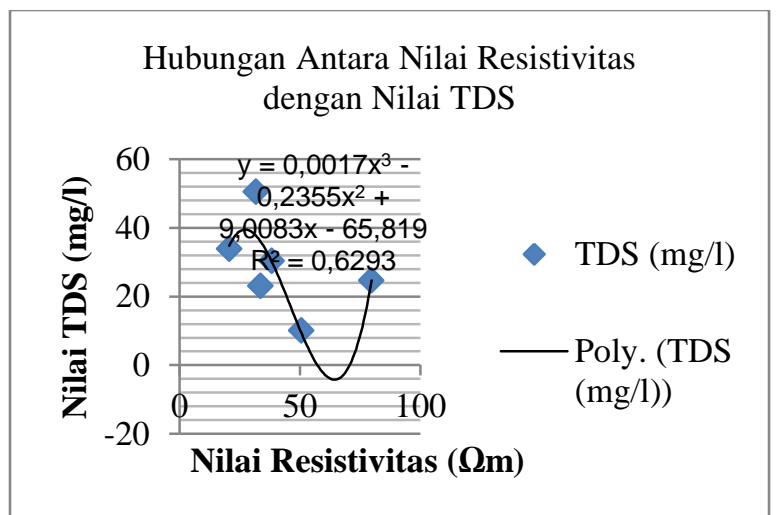

Gambar 7. Grafik Hubungan antara nilai resitivitas dengan nilai TDS

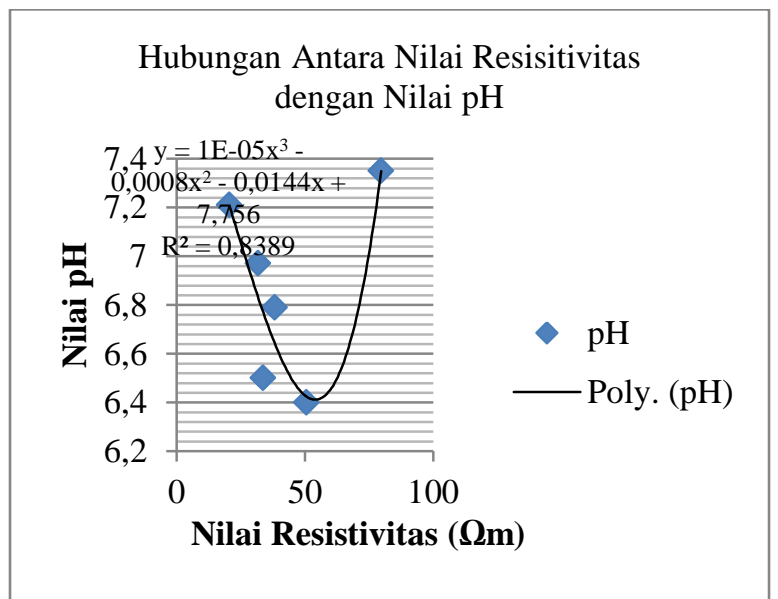

Gambar 8. Grafik Hubungan antara nilai resitivitas dengan nilai $\mathrm{pH}$

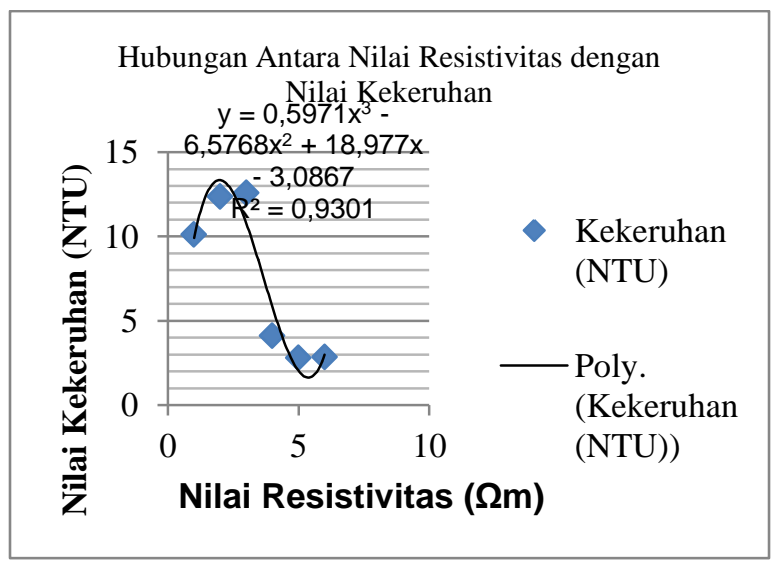

Gambar 9. Grafik Hubungan antara nilai resitivitas dengan nilai $\mathrm{pH}$
Dalam Penelitian ini rencana pelaksanaan pembelajaran, lembar kerja siswa, dan soal evaluasi telah divalidasi oleh tiga orang validator yang kompeten. Panelis pertama memberi penilaian Amat Baik pada 38 aspek dan Baik pada 10 aspek lainnya. Panelis kedua menilai Amat Baik pada 43 aspek dan Baik pada 5 aspek lainnya. Sementara Panelis ketiga menilai Amat Baik pada 44 aspek dan Baik pada 4 aspek lainnya. Jadi, dapat dikatakan bahwa penilaian terhadap RPP adalah amat baik.

Pada Validasi soal evaluasi, pedoman untuk melakukan penilaian oleh tiga orang validator menggunakan rubrik yang terdiri dari 4 aspek penilaian dan 20 indikator. Hasil data penilaian dari ketiga validator dianalisis secara manual untuk menentukan koefisien internal konsisten antara validator (Intraclass Correlation Coeficient atau ICC). Hasil analisis dapat dilihat pada tabel di bawah ini.

Tabel 8. Intraclass Correlation Coeficient (ICC) Tes

\begin{tabular}{|c|c|c|c|c|c|c|c|}
\hline $\begin{array}{l}\text { Sum } \\
\text { ber } \\
\text { Vari } \\
\text { an }\end{array}$ & Msp & Mse & Msb & b & $\mathbf{P}$ & $\begin{array}{l}\text { Tot } \\
\text { al }\end{array}$ & ICC \\
\hline $\begin{array}{l}\text { Pane } \\
\text { lis }\end{array}$ & $\begin{array}{l}0,08 \\
889\end{array}$ & $\begin{array}{l}0,46 \\
032\end{array}$ & - & - & 3 & $\begin{array}{l}0,00 \\
317\end{array}$ & \multirow{3}{*}{$\begin{array}{l}0,75 \\
862\end{array}$} \\
\hline Butir & - & $\begin{array}{l}0,46 \\
032\end{array}$ & $\begin{array}{l}0,46 \\
032\end{array}$ & $\begin{array}{l}1 \\
5\end{array}$ & - & $\begin{array}{l}0,13 \\
968\end{array}$ & \\
\hline $\begin{array}{c}\text { Erro } \\
\mathrm{r}\end{array}$ & _ & $\begin{array}{l}0,46 \\
032\end{array}$ & - & & - & $\begin{array}{l}0,04 \\
127\end{array}$ & \\
\hline
\end{tabular}

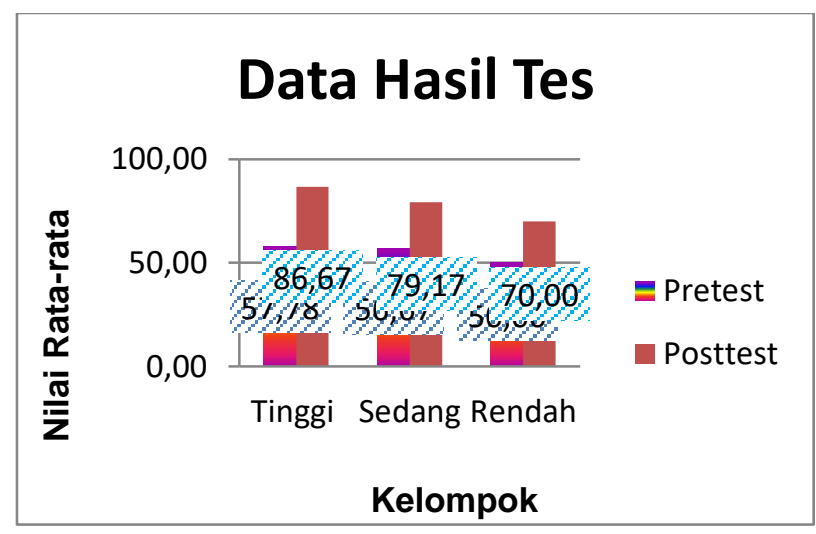

Gambar 10. Histogram nilai rata-rata Pretest dan Posttest 


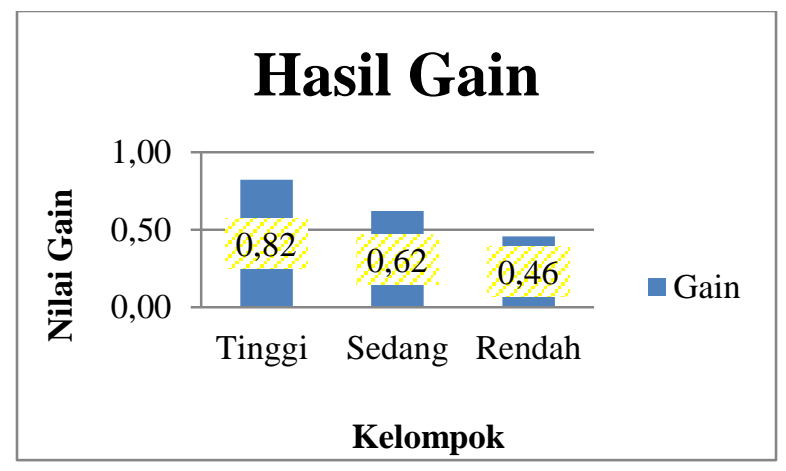

Gambar 11. Histogram gain

Tabel 9. Ringkasan Anova hasil perhitungan

\begin{tabular}{|c|c|c|c|c|c|c|}
\hline $\begin{array}{c}\text { Sum } \\
\text { ber } \\
\text { Vari } \\
\text { an } \\
\text { (SV } \\
\text { ) }\end{array}$ & $\begin{array}{l}\text { Juml } \\
\text { ah } \\
\text { Kua } \\
\text { drat } \\
\text { (JK) }\end{array}$ & $\begin{array}{c}\text { Deraj } \\
\text { at } \\
\text { Bebas } \\
(\mathrm{db})\end{array}$ & $\begin{array}{c}\text { Kua } \\
\text { drat } \\
\text { Rera } \\
\text { ta } \\
(\mathrm{KR} \\
)\end{array}$ & $F_{h}$ & $\begin{array}{c}\mathrm{F}_{\mathrm{ta}} \\
\mathrm{b}\end{array}$ & $\begin{array}{c}\text { Kesimp } \\
\text { ulan }\end{array}$ \\
\hline $\begin{array}{c}\text { Tota } \\
1\end{array}$ & & 19 & - & $\begin{array}{l}15, \\
42\end{array}$ & $\begin{array}{l}3, \\
59\end{array}$ & $\begin{array}{c}\mathrm{F}_{\mathrm{h}}>\mathrm{F}_{\text {tabe }} \\
1 \\
(15,42> \\
3,59) \\
\text { Jadi } \mathrm{H}_{\mathrm{a}} \\
\text { diterim } \\
\text { a untuk } \\
\alpha=0,05\end{array}$ \\
\hline
\end{tabular}

Berdasarkan hasil Pretest dan akhir pada kelas eksperimen diperoleh hasil yang ditunjukkan histogram gambar 10. Dari data di atas dapat dideskripsikan bahwa implementasi dari penelitian sains dengan model pembelajaran langsung (direct instruction), dapat meningkatkan hasil belajar siswa. Hal ini terlihat pada peningkatan rata-rata hasil pretest dan postest serta terlihat juga pada nilai kriteria uji gain.

Pada kelompok belajar tinggi berada pada kriteria gain tinggi bernilai 0,82 dan kelompok belajar sedang bernilai gain 0,62 serta kelompok belajar rendah berada pada nilai gain 0,46. Kriteria gain kelompok belajar tinggi berada pada kriteria gain tinggi sedangkan kelompok belajar sedang dan rendah berada pada kriteria gain sedang.

Dengan $\mathrm{dk}$ pembilang $5 \mathrm{dan} \mathrm{dk}$ penyebut 5, maka diperoleh harga $F_{\text {tabel }}$ pada taraf signifikansi $0,05=5,05$. Ternyata $F_{\text {hitung }}$ lebih kecil dari $\mathrm{F}_{\text {tabel }}(2,67<5,05)$.Dengan demikian dapat disimpulkan bahwa varian data yang dianalisis homogenya sehingga perhitungan Anova dapat dilanjutkan. Tabel 3. menunjukkan perhitungan uji Anova Satu Jalur (One Way Anova) hasil posttest pada taraf signifikansi 0,05 diperoleh $F_{\text {hitung }} 15,42>F_{\text {tabel }}$ 3,59. Jika terdapat perbedaan hasil belajar atau hipotesis nol $(\mathrm{H} 0)$ ditolak dan hipotesis alternatif (Ha) diterima maka menggunakan pembelajaran langsung (direct instruction) adalah efektif. Dengan demikian terdapat perbedaan hasil posttest antara kelompok tinggi, sedang dan rendah.

\section{KESIMPULAN}

Pada penampang inversi 2-D geolistrik, dapat diketahui bahwa lapisan yang mengandung air tanah tawar (freshwater) memiliki nilai resistivitas $31,8 \Omega \mathrm{m}-147 \Omega \mathrm{m}$. Lapisan yang mengandung air tanah tawar (freshwater) ditunjukkan bagian coklat hingga kemerahan dan merah hingga keunguan. Dari hasil penelitian menggunakan metode geolistrik resistivitas, kedalaman lapisan yang mengandung air tanah pada setiap lintasan memiliki kedalaman yang berbeda dengan kedalaman 1,25 m sampai 17,3 $\mathrm{m}$.

Kualitas air sumur pada lintasan titik pengukuran dengan menggunakan metode geolistrik berdasarkan nilai resistivitas yaitu: Sumur 5A lintasan 5 dengan besar resistivitas 20,6 $\Omega \mathrm{m}$, sumur 5B lintasan 5 dengan besar resistivitas $31,8 \Omega \mathrm{m}$ memliki kualitas air cukup, untuk sumur $1 \mathrm{~A}$ lintasan titik 1 dengan besar resistivitas $50,6 \Omega \mathrm{m}$, sumur 3B lintasan titik 3 dengan besar resistivitas $38,3 \Omega \mathrm{m}$, sumur $6 \mathrm{~B}$ lintasan titik 6 dengan besar resistivitas 33,7 $\Omega \mathrm{m}$ memiliki kualitas air cukup baik, sedangkan pada sumur 4A lintasan 4 dengan besar resistivitas $79,7 \Omega \mathrm{m}$ memiliki kualitas air baik.Dari data kualitas air, semakin besar resistivitas yang diperoleh maka kualitas air sumur semakin baik.

Berdasarkan grafik hubungan antara skor nilai parameter uji kualitas air dengan nilai resistivitas didapatkan nilai korelasi $\mathrm{R}^{2}=0,5818$ dikategorikan berkorelasi kuat. Hal ini menunjukkan bahwa skor nilai parameter uji kualitas air terhadap nilai resistivitas mempunyai korelasi kuat dengan 58,18\% variabel dependen yaitu skor nilai parameter uji kualitas air dapat 
dipengaruhi variabel independen yaitu nilai resistivitas, sedangkan $41,82 \%$ dijelaskan oleh faktor ataupun variabel lainnya (variabel independen lainnya diluar model).

Pembelajaran dengan model pembelajaran langsung (direct instruction) dapat meningkatkan hasil belajar siswa pada aspek kognitif (pengetahuan). Peningkatan hasil belajar pada aspek kognitif dapat dilihat dari nilai rata-rata pretest, posttest dan nilai rata-rata gain pada kelas XII MIA 2 yaitu kelompok Tinggi berada pada kriteria tinggi dengan nilai gain 0,82 pada kelompok sedang berada pada kriteria sedang dengan nilai gain 0,62 dan pada kelompok rendah berada pada kriteria sedang dengan nilai gain 0,46. Pembelajaran dengan model pembelajaran langsung (direct instruction) setelah diuji Anova Satu Jalur (One Way Anova) diperoleh $F_{\text {hitung }}$ Lebih besar dari $F_{\text {tabel }}$ $(15,42>3,59)$, maka hipotesis alternatif (Ha) diterima.

\section{DAFTAR PUSTAKA}

Arikunto. (2006). Prosedur Penelitian Suatu Pendekatan Praktik, Edisi Revisi VI. Jakarta: PT Rineka Cipta.

Lestari, S., \& Premono, B. T. (2014). Penguatan agroforestri dalam upaya mitigasi perubahan iklim: kasus Kabupaten Bengkulu Tengah Provinsi Bengkulu. Jurnal Penelitian Sosial dan Ekonomi Kehutanan, 11(1).

Nur, M dan Kardi, S. (2000). Pengajaran Langsung. Pusdat Sains dan Matematika Sekolah Program Pasca Sarjana.UNESA.

Ratnasari, Wita dan Suliyanah (2013).Pengaruh Penerapan LKS Dalam Model Pembelajaran Langsung Terhadap Hasil Belajar Siswa Pada Materi Kalor Di Kelas XI Multimedia SMK Negeri 1 Boyolangu Tulungagung.Jurusan Fisika, Fakultas Matematika dan Ilmu Pengetahuan Alam, Universitas Negeri Surabaya.

Sangkoro, Djoko. (1979). Teknik Sumber Daya Air. Jakarta: Erlangga.

Suhendra, (2005) .Penyelidikan Daerah rawan Gerakan Tanah dengan Metode Geolistrik Tahanan Jenis.Gradien Vol.1 No. 1 Januari 2005. Universitas Bengkulu.
Telford, W. M; Geldart, L. P; Sherif, R.E dan Keys, D. D. (1976). Applied Geophysics First Edition. Cambridge University Press. 